\title{
Insights of Feminist Epistemology in Some Selected Novels of Alice Walker
}

\author{
Dolly Sharma' \& Jaya Dwivedi ${ }^{2}$ \\ Assistant Professor, Parthivi College of Engg. E Mgmt. Bhilai, C.G ,India and Research \\ Scholar in the Department of English at N.I.T Raipur, C.G, India. \\ Email: dollyjayam2016@gmail.com. \\ Assistant Professor in the Department of English at N.I.T, Raipur, C.G, India. \\ Email: jdwivedi.eng@nitrr.ac.in.
}

Received February 23, 2017; Revised March 24, 2017; Accepted April 1, 2017; Published May 7, 2017.

\begin{abstract}
Alice Walker as a radical feminist presented the issues related to Gender feminism through articulation of protagonists highlighting the racial and gender inequality. The feminist epistemology theory is applied which believes that knowledge claims are made from nowhere and are universally valid. African women took surface knowledge of American society and gained superior knowledge of human potential. Alice Walker's various protagonists Meridian, Celie, Lissie and Tashi signify the situated knowers theory. They articulated their sufferings and attaining their own world of peace by changing the economic, political and moral status with love around them. Alice Walker deals with female consciousness through various thematic motifs. The motifs are regeneration of self, exploration of ethics by preserving African culture and last motif is to raise voice against sexual politics. Walker through her selected novels tried to document the anguish, pain and inferiority that black women were subjected. In the end of selected novels for study these protagonists explore their journey of loneliness, oppression, guilt and self-doubt towards self-acceptance, empowerment and love. Alice Walker as a situated knower advocated for equal rights and believes that freedom, education and responsibility tent to develop a woman into a noble woman. Application of feminist epistemology theory justifies Walker's optimism that the game is not lost as long as one plays it with the belief that it can be won.
\end{abstract}

Keywords: radical, feminist epistemology, situated knower, sexual politics, empowerment

Black women have been living in special circumstances despite in the United States. June Jordan emphatically expresses the special paradox of black womanhood, "to be black and to be a woman, to be a double outsider, to be a woman, twice oppressed, to be more than invisible. That is a triple vision." (Manvi 8)

The black women faced cruelty and violence in America. Evil of racism and sexicism exist in America. In America people face sytemic racism (which is something people of colour suffer and excluding whites) and personal animus or bigotry (which anyone, of any colour, can harbour Majority of daisporic Americans are feeling insecure in under the new American President Trump's rule. The challenges against racism and sexism faced by women of colour are explained through Feminist Epistemology. It is a term which was first coined in 1995.It is a theory of knowledge, from a feminist standpoint. Elizabeth Anderson describes Feminist Epistemology as being concerned with the way in which gender influences our concepts of knowledge and (c) AesthetixMS 2016. This Open Access article is published under a Creative Commons Attribution Non-Commercial 4.0 International License (http://creativecommons.org/licenses/by-nc/4.o/), which permits non-commercial re-use, distribution, and reproduction in any medium, provided the original work is properly cited. For citation use the DOI. For commercial re-use, please contact editor@rupkatha.com. 
"practices" of inquiry and justification'. Feminist epistemology examines the theory of knowledge from three dimensional perspectives of Feminist Standpoint theory, Feminist Post-modernism and Feminist Empiricism. Situated knower claims what is known, and the way it is known reflects the situation of perspective of the knower according to the standpoint of position of subject and circumstances of society. Feminist Post-modernism talks of instability of social identity of women. Feminist Empiricism combines observation of feminism through evidences provided by theories.Alice Walker being radical feminist presented the issues related to Gender Feminism and through articulation of protagonists highlighting the racial discrimination and gender inequality.

Alice Walker has emerged as a strong and independent women writer.She uses her novel as vehicles to familiarize her readers with the real struggles women face in the society. Alice Walker's protagonists react physically, intelligently and emotionally to a variety of situations. As a Situated Knower Alice Walker's turf deals with female consciousness especially black female circumstances distilled in a number of familiar thematic motifs. The 'Situated Knower' is expressed in detail through Feminist Epistemology.The viewpoint of Feminist epistemologists is"Knowledge claims are always socially situated"(Harding 1993,54)".Feminist theory of knowledge is a relatively new development of feminist philosophy. According to them, each epistemic agent occupies a position in one or more social groups (Webb 1995, 84) It is the class, gender, and racial background that cause impact on one's way of knowing. The main social aspect of knowing is feminist epistemology investigates is the identity of gender. In short, knowledge claims are made from nowhere and are universally valid as they are socially and historically constructed. In an absolute manner subject and object, subjectivity and objectivity, and nature and culture are dichotomized in an absolute manner. To claim epistemic privilege over socially and politically contested topics on behalf of the perspectives of systematically disadvantaged social groups, standpoint theory came into existence. African-American women have used alternative ways of producing and validating knowledge. African women took surface knowledge of American society. Then they tried to educate themselves and gain superior knowledge of human potentialities. Finally the African women claim to offer a re-presentation of the social world in relation to universal human interests.

Feminist epistemology conceives of knowers as situated in particular relations to what is known and to other knowers. What is known, and the way that it is known, thereby reflects the situation or perspective of the knower. In Meridian, Alice Walker depicts the plight and challenges faced by Meridian and underscore her position as a Situated Knower.She understood the motherhood concept when she herself became mother.

She was only seventeen. A drop out from high school, a deserted wife, a mother, a daughter-in-law." (Meridian 75-76).

Another aspect of situated Knower is found in The Colour Purple depict with politics of sex and politics of class and race speaks that People often represent objects in relation to their emotions, attitudes and interests. Gender is what societies make of sexual differences: the different roles, norms, and meanings they assign to men and women and the things associated with them on account of their real or imagined sexual characteristics. Gender thus has several dimensions (Haslanger 200o). Its unrelenting, severe attack on male attitude, especially the violent abuse of black women by black men, is offered as a revolutionary leap forward into a new social order based on sexual exploitation.. Collins (1990) grounds black feminist epistemology in black women's personal experiences of racism and sexism, and in cognitive styles associated with black women. She uses this epistemology to supply black women with self-representations that enable 
them to resist the demeaning racist and sexist images of black women in the wider world. The Colour Purple originates from the perspective of Situated Knower. In The Colour Purple Sofia who "modifies" the requirement of marriage and child-rearing and encourages Celie to search for her identity represents the epistemic violence. (Gayatri Spivak,Can the Subaltern Speak), According to Spivak, epistemic violence occurred through the marginilization of certain voices within Western discourses. These voices belong to the "subaltern."The African women belong to the category of subaltern. The female characters and knower of the novel metamorphoses at various stages and emerge as butterflies. They were able to break their chains of enslavement through the feeling of sisterhood creating their own world of peace by changing their economic, political and moral status with love.

The Temple of my Familiar, yet another novel of Alice Walker reflects cherished beliefs and the opposition of womanism to patriarchy. The central protagonist of this novel, Lissie as a Situated Knower seeks identity and root through their ancestors. She takes birth in different races and at different times. In Zede's tale of her youth she exposes African slave trade through her horrific recollections of slavery. Lissie articulates the voices of the characters representing different cultures, economic classes and historic eras. The epistemic violence is expressed through tales describing the patriarchal system carried in the jungle of Africa and South America. In The Temple of My Familiar the matriarchal heritage is well described by Miss Lissie and Zede, biological mothers teaching lost ideals of harmony. These women are examples of subordinate group and they had to use alternative ways to create independent self-definitions, self-valuations and rearticulate them through their own specialists. Traditionally, the suppression of Black women's ideas within Whitemale-controlled social institutions led African-American women to use music, literature, daily conversations, and everyday behavior as important locations for constructing a Black feminist consciousness. More recently, higher education and the news media have emerged as increasingly important sites for Black feminist intellectual activity. Within these new social locations, Black feminist thought has often become highly visible, yet curiously, despite this visibility, it has become differently subjugated (Collins 1998a, 32-43). Walker's perspective on race, feminism, love, marriage and Africa is epistemologically represented. Lissie as a situated knower, has unfolded drastically the womanist meaning of freedom and the problems of woman in contemporary era. According to Acharya, women as a Situated Knower once enjoyed a proper place in the social order but men grew jealous of woman with passage of time. Alice Walker's novel signifies that as a situated knower then women fight for their rights and regain their due place in society.

The quality of a woman as described by Earliest Acharya:

A woman should be like a slave while working/serving, a minister when counselling/advising. Goddess Laxmi in her looks/personality: the earth in forbearance/endurance, a mother while feeding, Rambha the celestial prostitute in bed (Cited in Alladi,2-3)

Tashi,in Possessing the Secret of Joy as a Situated Knower tries to solve the most controversial issues of the time, the female genital mutilation. The sufferer of situation is the protagonist Tashi of African origin and later became Evelyn, in the United States to heal her physical and psychological illness. Tashi-Evelyn represents the idea of "two souls, two un-recon ciled strivings; two warring ideals in one dark body."Through Tashi Alice Walker examines the soul of her protagonist and feels that this practice of genital mutilation makes African women joyless and spiritually dead. Tashi as a situated knower faces this barbaric practice and through psychoanalysis blaming her culture. She decided to return back to Africa and take revenge for her 
own torture and the death of her sister, a victim of circumcision. Alice Walker considers Tashi as a martyr and considers female circumcision as a "blatant" symbol of the oppression of women. This novel depicts the tale of woman, about women which advocated the right of women, which ensures that African women will continue to "possess the secret of joy". This novel and her character, Tashi totally fits in the concept of situated knower.

Alice Walker's various protagonists Meridian, Celie, Fanny, Carlotta, Tashi signify the Situated Knower's theory where the women are marginalized by society and victimized by men and race. These women face adversities of life boldly and achieve wholeness in the end by developing their self-identity. Celie in The Colour Purple raises herself to the level of autonomy. She wears the royal robe of Purple signifying herself as a situated knower and attains self-esteem and wholeness.

On the other hand, Meridian believes herself and rejects the traditional values and lives for the present and future. becomes self-sustained. The Temple of My Familiar highlights the rejection of the traditional standard of colonized sexuality and the lovers achieve oppression free happiness. Similarly Lissie as a situated knower was successful in attaining control over patriarchy. Thus Walker yearns for black women to reach this conclusion.

\section{Background: the work of Alice Walker and shades of Feminist Epistemology}

As a Situated Knower Alice Walker's turf deals with female consciousness especially black female circumstances distilled in a number of familiar thematic motifs. The first motif of Alice Walker is to regenerate self, as she believes that it is possible to transform them. Walker makes the readers feel that her protagonist in various novels abandon their old tradition, attitudes and assumptions and embrace themselves with a new lease of life. Celie, in The Colour Purple, Trauman Hill in the 'Meridian', Tashi in 'Possessing the Secret of Joy' are examples of such transformed identities. The character of Lissie of 'The Temple of my Familiar' is also very well articulated by Alice Walker expressing that when a person dies, her soul momentarily returns to its primal, not necessarily in human form but to other incarnations. Lissie had a unique power in the novel to incarnate successively, lifetime after lifetime. Epistemological choices about whom to trust, what to believe, and why something is true are not benign academic issues. Instead, these concerns tap the fundamental question of which versions of truth will prevail.

The second motif of Alice Walker's novel which expedites the situated knower's theory is exploration and quest for self. She believes that human life is a journey which takes place in the harder road where a continuing process of growth and discovery takes place.

Walker's character also faces the path of danger, personal adventures, possibilities, changes and finally triumph. As a Situated Knower, the face of adversity and abuse is represented by Celie in The Colour Purple, the embodied strength and dedication is shown by Meridian in Meridian and the imagination and resilience is well demonstrated by Lissie and Tashi , protagonists of The Temple of my Familiar and Possessing the Secret of Joy.

Alice Walker's third motif of writing which is identified by Barbara Christian as a Situated Knower is "a sense in which the 'forbidden' in the society is consistently approached by Walker as a possible route to truth" (Black feminist Criticism,40).Walker brings out her characters from their own life circumstances and questions the social and cultural belief for justice. She highlights personalist idealism, an idealism that lies beyond axiological or moral categories.(Dieke 8-9)

Black women started writing with four dimensions of Black feminist epistemology. They talked of their lived experiences with the criterion of meaning, the use of dialogues, the ethics of personal 
accountability, and the ethics of caring. These core themes and interpretive frameworks of Black women's knowledge informed by Black feminist epistemology ensued a rich tradition of Black feminist thought. Alice Walker through her novels tried to explore ethics of personal accountability by preserving the African culture and fiercely asserting her own experiences satisfying Situated Knower's concept.

The fourth motif of Alice Walker's writing exposing the sexual politics in almost all her novels. Even I found it almost impossible to let her say what had happened to her as she perceived it ... And why? Because once you strip away the lie that rape is pleasant, that children are not permanently damaged by sexual pain, that violence done to them is washed away by fear, silence, and time, you are left with the positive horror of the lives of thousands of children ... who have been sexually abused and who have never been permitted their own language to tell about it. Alice Walker 1988, 57

Regulating Black women's sexualities emerges as a distinctive feature of social class exploitation, of institutionalized racism, of U.S. nation-state policies, and of gender oppression. In essence, this approach suggests that both the sexual meanings assigned to Black woman's body as well as the social practices justified by sexual ideologies reappears across seemingly separate systems of oppression. Alice Walker's women have suffered physical and verbal abuse from men and from society .She expressed this through her poetry collection and novels. Black poet June Jordan has called these black woman "black eyed Susan-flowers of the blood-soaked American soil (Qtd Washington 40).Celie, Tashi and Meridian had also undergone pains and sufferings in their life. The art of Walker's writing describes a wounded self--a self that is private, feminine, and social. These women characters suffered the situation of physical and psychological sufferings. Their sufferings can be minimise through empowerment. As standpoint theory says, when it comes to knowledge, Black women's empowerment involves rejecting the dimensions of knowledge that perpetuate objectification, commodification, and exploitation. Being empowered means when we understand and use those dimensions of our individual, group, and formal educational ways of knowing that foster our humanity. When Black women value our self-definitions, participate in Black women's domestic and transnational activist traditions, view the skills gained in schools as part of a focused education for Black community development, and invoke Black feminist epistemologies as central to our worldviews, we empower ourselves. C. Wright Mills's (1959) concept of the "sociological imagination" identifies its task and its promise as a way of knowing that enables individuals to grasp the relations between history and biography within society. Resembling the holistic epistemology required by Black feminism, using one's point of view to engage the sociological imagination can empower the individual. "My fullest concentration of energy is available to me," Audre Lorde maintains, "only when I integrate all the parts of who I am, openly, allowing power from particular sources of my living to flow back and forth freely through all my different selves, without the restriction of externally imposed definition" (1984, 120-21). Developing a Black women's standpoint to engage a collective Black feminist imagination can empower the group.

Alice Walker's final motif of writing is the holistic approach towards life felt by a feminist .Walker's fiction thoroughly examines black women's experiences and finds them to be painful. Walker depicts the myth of black mother's as the rock of Gibraltar and black wives and lovers as super bithches. The fact that black women accept these stereotypes as true is not only injustice but they themselves are responsible for suppressing their identity and creativity. By calling attention to a number of oppressive forces to which women are subject, Walker wants the reader to realize the gradual development in the psyche of her women protagonists. The women 
characters in the novels of Alice Walker are not role models for black women. They are women with specific problems in a male dominated world. The black women protagonists Lissie, Meridian, Celie, Fanny ,Tashi and Shug fought for their identity and survival. They ultimately overcame the obstacles and were contented with life.

When the feminist theory of Situated Knower is applied to Alice Walker's novels, it shed light on the plight of the African women in America and highlights the struggle they carry on in order to liberate themselves from violence and oppression. This reminds Maya Angelou's words: "The black female is caught in the tripartite crossfire of masculine prejudice, white illogical hate and black lack of power." (15).Afro-American writers insist that the black people must assume responsibility for their behaviour. In spite of racism, these writers say that the black people still have the responsibility to attempt, to nurture their dignity and self-esteem. The spotlight here is on the women for whom the task of self-nurturance, the quest for self-hoods is even more challenging. They document the anguish, pain and often the inferiority that Black women suffer from when their own men slight them for straight-haired, fair-skinned women. But by the conclusion of the novels, the heroines learn to appreciate their own singular beauty. They become subjects but not objects for another's ambition and trade roads leading to destinies of their own choice. They develop and mature frequently of painful and lonely process, but they realize that they have to confront not only their strength but also their weakness. They learn that to love another they must first learn to love themselves.

As Barbara Smith, pointed out "the politics of sex as well as the politics of race and class are cruelly interlocking factors in Black women's literature" (Mary Eagleton 78).

Her writings articulate an exploration of women from her journey of loneliness, oppression, guilt and self- doubt to self-acceptance, empowerment and love. The protagonists of various novels of Alice Walker undergo transformation of individual heart, away from brutality and meanness towards strength and self-direction. In a nutshell Walker very well-articulated the quest of identity and autonomy, along with their need for achievement and self-fulfilment.

Meridian is a maturation novel, an examination of Meridian's growth, her movement into womanhood and her emergence as a strong woman. Walker constructs for her protagonist a lonely pilgrimage that encompasses elements of the universal mono myth: initiation, renunciation, atonement and release. Meridian as a Situated Knower describes her quest as self knowledge, for wholeness that leads to transcendence, as Meridian finally discovers herself and her relationship to the world at large.

Commenting on the structure of Meridian, Alice Walker says, "I wanted to do something like a crazy guilt... a crazy guilty story is one that can jump back and forth in time, work on many different levels and one that include myth". Perhaps that is why Walker has adopted the guilt structure for her novel of a black woman quest for identity and her role in life. Meridian succeeds in making something useful \& beautiful out of the apparently disjointed bit of her life and experiences. Thus, there is perfect harmony between the content and form in this novel relating to black American women.

Afro-American women express themselves in their own ways as Celie does through her letters in the novel.In her most talked about essay 'Self-Definition', placing contemporary Afro-American women's fiction, Barbara Christian remarks that The Colour Purple articulates one of the major concerns of the 8o's. That is sexicism must be struggled against in Black communities and that sexicism is integrally connected to racism. But more importantly where other novels have failed to come up with a solution, The Colour Purple seems to suggest that Black woman by creating 
empowered sisterhood could rectify present day definition of women and men. Black women's petition in the family and the importance of sisterhood has attracted attention from various critics and writers. At the beginning of the novel-early as Celie first letter to God the reader come to know that Celie is being sexually abused by her father but in her last letter to Nettie, Her free, self-sufficient, womanist identity may be traced in the lines that follow:

"Dear Nettie. I am so happy. I got love,

I got work; I got money, friends and time.

And you alive and be home soon.

With our children." (TCP 38$)$

Thus, it can be easily analysed that the theory of Situated Knower helps to understand Celie's evolution as a journey from innocence to experience, ultimately leading to wisdom and awareness.

In her writings, Walker exposes the global scope of the objectification of women's bodies, while differentiating the racialized exploitation of woman's bodies under slavery.

In The Temple of My Familiar through Lissie many lives she enumerates the physical horrors of the female slave experience. She has portrayed her female characters capable of breaking the bonds of oppression and discovering diversity in all human and non human elements, their hair being chopped off, their bodies branded with pieces of hot iron and put on display as well as being subjected to repeated violation, physical punishment and endless breeding leading to death.

Lissie exclaims-

"The men had decided that they would be Creators, and they went about dethroning women systematically. To sell women and children for whom you no longer wished to assume responsibility....became a new tradition, an accepted way of life." (ToMF 64)

Another novel of Alice Walker, Possessing the Secret of Joy highlights important titbit shared by a Situated Knower because Tashi in the novel appears to be a victim of circumcision practice in Olinkan society of Africa. She realized the self is the essence of human wholeness and it is what makes the individual different from others. These archetypal symbols can be experienced through the individualization process or the path to wholeness. Ultimately these factors enrich the self and connect it to the individual resulting the individual being a unique being.

\section{Critical Opinion on Alice Walker's Epistemological View}

\footnotetext{
The first among the blessings for which Plato thanked the God was that he had been created free, not enslaved, the second, a man, not a woman.( Beavoir.1953;xxi)
}

Above lines describes the indescribable hostility and discrimination faced by woman as a Situated Knower. Plato, if had taken his place in the later date, he would have added the words and for not beings an African-American woman. An African ancestry and an American contemporaneousness make African-American woman a hybrid personal.

Alice Walker has raised a voice for depicting and documenting the plight of African American immigrants in America, more specially African women, and filled a gap because even though a lot has been said about Asian American, Chinese, Hispanic and other immigrants. Alice Walker adds 
several dimensions to her stories by depicting the struggles of her female characters in both Africa and America and how they emerge stronger from it. She takes Black feminism into account. This also added weight to Walker's place as a Situated Knower in the context of feminism as she expresses in one of her novels:

"I don't know if I could kill anyone. ... If I had to do it, perhaps I could . . . I would defend myself . . . Maybe I could sort of grow into the idea of killing other human beings .... But I'm not sure...I don't know."(Meridian 45-60)

La Grone compares Walker's depiction of the black men to "Black male bashing"1 and, as La Grone notices, David Bradley even wrote that "her writings were troubling because they suggested that the author had a high level of enmity toward black men."2 The redefinition of God as a necessary requirement of womanist emancipation is described by Celie's words: "Trying to chase that old white man out of my head."(Walker 204)

Some critics perceive womanism concept of Alice Walker as an atheistic conception. For example Willis argues:

Womanist theology [...]source. For the womanist theologian, God is not the first principle, but, rather, the autonomous Black woman who will freely make whatever choices she wishes to make - choices determined by her is based on non-Christian ideology. It begins with culture, rather than with God and the Bible as the primary own self-will, independent of God. (Willis 36).

In almost all the novels of Alice Walker mythology there is the concept of myth. Myth inspire the realization of the possibility of your perfection (and) the fullness of your strength(...)Myths grab you somewhere down inside(.......They)are infinite in their revelation (Power 39,175,183)

A visionary and archetypal doctrine of African -American feminism is seen when mythical Black Mother, in order to live for her children sacrifice her individual personality and ideology. The African-American feminism includes the sorrel bond of acceptance of sexual and non-sexual love for men and women's strength. It also includes, the preference for women' culture, a commitment to the survival and wholeness of black people. Alice Walker in her mythic narrative describes historical and cultural plight of poor oppressed black women which is narrated in The Colour Purple as "heroic female selfhood" .In the analysis of The Colour Purple: the protagonist achieves her heroic female selfhood through empowering subjectivity."This recognises Walker's recognition of the culture's need for an African American female hero.

The danger of the myth of Black Motherhood is described by Barbara Christian according to this tradition, only stories of strong, successful mothers are passed on: . . . that tradition that is based on the monumental myth of black motherhood, a myth based on the true stories of sacrifice black mothers performed for their children is ...restrictive, for it imposes a stereotype of Black women, a stereotype of strength that denies them choice and hardly admits of the many who were destroyed. (89) .The tradition of Black Motherhood is well-depicted in Meridian when her own mother tries to obey these old traditions by suppressing her own emotions. She feels that motherhood feeling takes away independence of victim. In this novel another victim, Nelda, Meridian's girlhood friend who wanted to go to college, but since she became a mother at age fourteen, she never finished high school. In another part of novel, Fast Mary's pregnancy leads to her death as heavy belly of the pregnant Wild Child limits her ability to move out of the path of the car that kills her. Meridian 's own sacrifice-of giving up her child-is as painful and trying but it is a case of wilful neglect .Walker try to attempt traditional and feminist perspective in 
compromising terms thus allowing her protagonist to live. Radical feminists blamed motherhood as a dead end and waste in women's lives. Walker acknowledged in the novel that a mother in this society is buried alive, walled away from her own life, brick by brick. Yet the novel is based on Meridian's insistence on the sacredness of life. (90) Meridian through this novel conveys the role of mother particularly The Mythical Black Mother, in order to live for her children should sacrifice her individual personality and concerns .Meridian doesn't agree to follow this norms and ultimately gave her child for adoption. This lead to development of cumulative guilt in her which Miss Winter tried to remove and once guided her for school speech, realized the weather was too warm for mink and took off her coat. (122) Miss Winter breaks the custom of accepting this speech by admitting to Meridian that, although she had once recited the words, she had not believed they were true. This is the first time that an older woman has given an honest, useful piece of advice to Meridian, and Miss Winter is rewarded immediately for her good act with feeling that allows her, for a time, to shed a layer of woman \& is prescribed respectability, the heavy Meridian feels completely weighed down by guilt for not living up to her mother's standards: It seemed to Meridian that her legacy from her mother's endurance, her unerring knowledge of rightness and her pursuit of it through all distractions, was one she would never be able to match (M 124).

In Temple of My Familiar, Zede described history and mythology of South America to Arveyda when women were priestesses of a mujer muv arande, a goddess who produced the earth. The birth process was a mystery to men and it was the men who made women into priestesses .Later Zede tells that men and women have changed roles. The men became priests and felt that they should be somewhat feminine. The creative talents of women started developing with this metamorphosis and women used this talent to adorn the male priest. With their roles changed, women started using their creative talents to adorn the male priests. But they considered mother's creativity as "holy work". Winchell mystically observes:

Walker and its history of the world as traced through her novel and African and South American characters records the pattern of freedom an alternating between times when men and women could and did live together more or less in harmony and times when harmony was best maintained by living apart. But need to dominate and dethrone woman recurs periodically, however, and each time the two sexes enter a period of uneasy cohabitation.(Winchell 1992, 117)

Another mythological element discussed in the novel is the word 'Africa' which brings to Arvedya the memories of his dead mother Kathering Degos. She was like the strong African woman who exposed herself to what she wanted and made clear what she didn't want and took risks (Gayles,393) .

In the end of the story, Suwelo and Fanny, Carlotta and Arvedya return to the life style of their ancestors in order to achieve spiritual freedom. They decided to live apart from each other to achieve harmony in their life. Walker believes that there should be personal effort by man-woman to recapture their identity and individuality. In one of her interviews with Tate she says.

I think my whole program as a writer is to deal with history just so I know where I am. I can't move through time in any other way, since I have strong feelings about history and the need to bring it along. One of the scary things is how much of the past, especially our past, get. (Walker 1983b, 185)

Feminist epistemology is in part motivated by the recognition that each epistemic agent occupies a position in one or more social groups (Webb 1995,84) which is supported by Harding with these statement:"knowledge claims are always socially situated" (Harding1993, 54). How we 
conceptualize things and what kind of standard of epistemic inquiry we use are socially and historically decided. One's way of knowing is affected by one's class, gender, and racial background. The gender identity of the knower is the main social aspect of knowing that feminist epistemology investigates, although it is not investigated in isolation from other social aspects such as class, race, and culture.

All feminist epistemologists have criticized traditional Western epistemology because according to this epistemology, knowledge claims are made from no particular time, location, circumstance, and perspective, and therefore they are true in all situations and from all perspectives. In short, knowledge claims are made from nowhere and are universally valid. Such an epistemology clearly denies that knowledge is socially and historically constructed. It dichotomizes subject and object, subjectivity and objectivity, and nature and culture in an absolute manner. It values rationality and abstraction and devalues emotion and the concrete. For feminist epistemologists, traditional Western epistemology is andocentric and male-biased. It fails to take women's experience and perspectives into account. Due to the existence of male domination, male norms have become dominant norms and been regarded as objective and universal standards for all. Accordingly, women and their ways of thinking and knowing have been considered something inferior and invalid.

According to feminist epistemologists, such male-bias has severely hindered the advance of philosophy and science. For example, due to devaluing femininity, the knowledge that mothers have of children is not greatly appreciated (Anderson 1995, 50). In general, the more a kind of knowledge is associated with femininity, the less value it will be assigned.

\section{Conclusion}

As a Situated Knower the African American women faces "double jeopardy 'of belonging to the "inferior sex" of an "inferior race". Facing the situation of marginalization and the basic identity conflict these women boldly struggle to protect, preserve and transform the Negro community. The Feminist move helps them to achieve dignity and respect in the face of discrimination and intolerance. According to Gerda Lerner:

"The oppression of the slave woman was more direct, more brutal and without redeeming features. The black woman was exploited as a worker, as a breeder of slaves and sex-object for white men." (Majority Find its Past 70)

Contrary to this, Collins (1990) grounds black feminist epistemology in black women's personal experiences of racism and sexism. She uses this epistemology to supply black women with selfrepresentations that enable them to resist the demeaning racist and sexist images of black women in the wider world, and to take pride in their identities. Black Feminist Consciousness helped millions of black women to survive with their tenacity of spirit, a gift of endurance, a steadfast of aspiration. The fortuitous forces and these transformations help the black woman to articulate the "inner speech". These brought literary tradition for African women which created new milestones and help them to enter new doors of experiences.

Alice Walker as a Situated Knower not only belongs to that oppressed race but is also a member of oppressed sex. As a prolific writer her womanist view which means outrageous, courageous, audacious or will-full behaviour which is well expressed through her task. The protagonist in Alice Walker's novels truly represents Situated Knower which becomes emblematic to American life. Alice Walker gave voice not only to silent bitterness and hate but also represented kindness and 
sustaining love of her protagonists in her novels. The external realities facing women and the internal world of these characters are widely examined. The spiritual survival of her characters is well-explored in The Colour Purple, Possessing the Secret of Joy, Meridian and The Temple of My Familiar. Walker's novel populate as a situated knower regarding her ability to survive the threats given by the white society and black race.

Meridian, as a Situated Knower, realises in the end of the novel - who she can be, who she wants to be and who she is expected to be. This realization came after facing marginalization from society. Meridian as an existentialist chooses to become community mother and rejected the patriarchy standards of a perfect woman. She worked in the civil right movements, faced the struggle and eventually engages herself as to those meaning of mother who create, nurture and save life in social, physical and psychological terms. She articulated her feelings by speaking against racist patriarchy hegemony and bloom as a cultural self. The role of race and gender is well managed by Meridian in the end of the novel.

The Situated Knower concept is well illustrated through Alice Walker next novel The Colour Purple in which Celie a fourteen year scared girl who was persistently raped by her step-father. In such situation she expresses her feelings of despair by writing letters to God. She was deprived of motherhood as her own children were taken by her step father and sold. Facing the various adverse situations in her life she gets transformed into a tree. She became submissive, subordinate, obedient, enduring extreme physical and mental pain. Kaplan believes that, epistolary form is the most suitable form for dramatizing Celie's condition: while epistolary narratives may well embody a desire for exchange'... they are more likely to depict that desire as a thwarted one: letters are repeatedly lost, withheld, seized, misdirected, or misplaced ... An addressee who is absent, silent, or incapable of replying is one of the distinguishing characteristics of epistolary. (1996, 131)

To overthrow the indignities of her existence. She learned that resistance is necessary. The two women Shug Avery, Albert's mistress, Sofia, Harpo's wife brought drastic changes in Celie's personality and attitude. She became audacious and as a Situated Knower radically get aware with her own sexuality and creativity At the end of the novel she became independent woman.

Through Lissie,the protagonist of The Temple of my Familiar which includes many lives and characters from The Colour Purple, Walker weaves a pan cosmic world in which humans, animals and the whole ecological order co-exist in a unique dynamics of symbiosis. David Nicholson opines, "Walker's theme appears to be the difficulty of love, the pain men and women must pass through to find themselves and each other, for each of these couples must confront and overcome some internal crisis" (3).

Walker shifted her emphasis from the external conditions of the society to the internal psychological development of individual in Possessing the Secret of Joy. She turns specifically to Jung who has written extensively about the individuation process with its aims of bringing the questing individual to the state of spiritual maturity and peace. Jung identifies archetypes as the persona or mask of the false wrappings of the society acquitted by the individual, the shadow or the dark side of the duality. Jung seems to be emphasizing that it is not possible for anyone including woman to live with a split personality. Disintegration in every discipline of life is on the Dias and thus has taken both men and women in its grip. What matters more than anything else is what man and woman needs in order to make his or her life more meaningful and productive productivity is synonymous with creativity and it also include freedom of choice and freedom of articulation. 
Alice Walker, as a Situated Knower makes black women aware of their rights and conveys a message to the women that they should prepare themselves for the problems and challenges which are likely to come in their way. Alice advocated for equal rights and believes that freedom, education and responsibility tend to develop a woman into a noble woman. Through her writings she wants to make her women protagonists alive to their rights and enables a women to develop into a noble and rebellious one. Walker's fiction thoroughly examines black women's experiences and finds them to be painful. Walkers novels depicts the myth of black mother's as the rock of Gibraltar and black wives and lovers as super bithches of African society. The fact that black women accept these stereotypes as true is not only injustice but low. They are responsible for suppressing their identity and creativity. By calling attention to a number of oppressive forces to which women are subject, Walker wants the reader to realize the gradual development in the psyche of her women protagonists. Many of the black women protagonists such as Ruth,Meridean,Celie,Fanny ,Lissie,Tashi and Shug fight for their identity and survival and ultimately overcome the obstacles and comes into their own so as to prove that they are equal to man in many respects and disciplines. They serve as role models in order to set an example for other women to follow. Walker has succeeded in injecting into her novels a dose of optimism and seems to stress that the game is not lost so long as one plays it with the believe that it can be won.

Application of Feminist Epistemology theory in justifies that Walker's selected novels present the real situation of black women in America through the various protagonist in her selected novels. Prior research work of application of Situated Knowers theory in Bharti Mukherjee's novel justified the position of brown women in America. Bharti Mukherjee raised a feminist voice through the speaking characters of her novel and shared the complication of hardships faced of gender inequality and gender identity. On comparative ground of Alice Walker's and Bharti Mukherjee regarding 'Situated Knowers theory' one can conclude that knowledge claims are made from nowhere and are universally valid. Such an epistemology values lead the individual to explore themselves by articulating their feelings to attain personal identity and happiness. All women of various nationalities in short want the men in their life to be besides them

Don't walk in front of me, I may not follow

Don't walk behind me, I may not lead

Walk beside me and be my friend.

(Competitions Wizard, Feb.2003,9).

\section{References}

Lorde, Audre. 1982. Zami, A New Spelling of My Name.Trumansberg, NY: Crossing Press. Alcoff, Linda and Elizabeth Potten(Ed.).( 1993). Feminist Epistemologies, New York:Routledge. Angelou, Maya.(1983) Black Women Writers at Work, Chapter 1, by Claudia Tate .

Beauvoir, De Simon(2012)The Second Sex, Woman as Other, New York: Knopf Doubleday Publishing Group.

Belenky, Mary Field, et al, 1986, Women\&\#39;s Ways of Knowing, New York: Basic Books

Briens, O. (2007). Encyclopedia of African American Women Writers ,Yolanda William,Greenwood Publishing Group.

Carla Kaplan. (1996)The Erotics of Talk: Women\&\#39;s Writing and Feminist Paradigms, New York: Oxford University Press.

Christian, Barbara. (1985) Black Feminist Criticism, New York: Pergamon Press. 
Collins, Patricia Hill. 1989. \&quot;The Social Construction of Black Feminist Thought.\&quot; Signs: Journal of Women in Culture and Society 14:4,745-73

Collins, Hill Patricia. (1990) Black Feminist Thought, Boston: Unwin Hyman.

Deborah K. Heike's.(2012) The Virtue of Feminist Rationality, London: Continuum International

Publishing Group.

Dieke, Ikenne. (1999) Critical Essays on Alice Walker, London: Praiger Publication.

Eagleton, Mary. (1996) Black Women's Literature, Oxford: Blackwell Publishers.

Farris Robert (1974) African Art in Motion: Icon and Act, London: University of California Press.

Grone, La.(1987)Alice walker's The Colour Purple(Literary Criticism),New York: Kheven Edition,20o9

Harding, Sandra. (1993).Rethinking Standpoint Epistemology: What is 'Strong Objectivity”?,New York:

Haslanger, Sally, --, 200o, “Gender and Race: (What) Are They? (What) Do We Want ThemTo Be?”, 34(1): $31-55$.

Jordan, June. (1995) Poetry for the People: A Revolutionary Blue Print, California: Taylor and Francis.

Lerner, Gerda.(1979) The Majority Finds Its Past: Placing Women in History, New York: Oxford University Press.

Nicholson, David .(1989).Alice Walker Trips,The Washington Post.

Pearson,Carol \&amp;Kaherine Pope.The Female Hero in American and British literature.New York:R.R,Bowker,1987

Prasad, Amar Nath .(2002) Indian Writing in English: Critical Exploration, New Delhi: Arup and Son

Tolkien J.R.R.(1986) The Fellowship of the Ring: Being the First Part of The Lord of the Rings, Mass Market Edition.

Walker, Alice. (1976) Meridian, New York: Pocket Books Print.

-- -. The Color Purple(1982), London: Phoenix Paperback, Print.

-- -. Possessing the Secret of Joy (1989), New York: Pocket Books Print.

-- -. The Temple of My Familiar (1992), New York: Pocket Books Print.

Willis , Womanist Theology, Black Women\&\#39;s Voices, New York :Print.

Wade-Gayles, Gloria. 1984. No Crystal Stair: Visions of Race and Sex in Black Women\&\#39;s

Fiction. New York: The Pilgrimage Press.

----. 1990. \&quot;Black, Southern, Womanist: The Genius of Alice Walker.\&quot; In Southern Women

Writers: The New Generation. Ed. Tonette Bond Inge. Tuscaloosa, Alabama:The University of Alabama Press.

Walker, Robbie. 1987. \&quot;Coping Strategies of the Women in Alice Wlaker\&\#39;s Novels:

Implications for Survival.\&quot;journal 30 4: 401-439;8.

Walker. Melissa. 1991. Down from the Mountaintou: Black Wcmen\&\#39;s Novels in the wake of

the Civil Rights Movement, 1966-1989. New Haven: Yale University Press.

Winchell, Donna Haisty. 1992. ALice Walker. New York: Twayne Publishers.

McDowell, Deborah E. 1981. \&quot;The Self in Bloom: Alice Walker\&\#39;s Meridian.\&quot; CLA Journal 24 3: 262-275.

McGowan, Martha J. 1981. \&quot;Atonement and Release in Alice Walker\&\#39;s Meridian.\&quot; Critique 23 1: 25-36.

Madhubuti (Chicago: Third World Press, 2007); Jeffrey Louis Decker, The Black Aesthetic Movement (Detroit: Gale Research Co., 1991).

Situated knower's concept(Mary Field,1986,15)

Dolly Sharma is Assistant Professor, Parthivi College of Engg. E Mgmt. Bhilai, C.G ,India and Research Scholar in the Department of English at N.I.T Raipur, C.G, India. Email: dollyjayam2016@gmail.com.

Jaya Dwivedi is Assistant Professor in the Department of English at N.I.T, Raipur, C.G, India. Email: jdwivedi.eng@nitrr.ac.in. 